\title{
PENERAPAN PAYMENT GATEWAY DAN ANTRIAN PADA PEMESANAN KULINER DI PURWOKERTO BERBASIS ANDROID
}

\author{
Dwi Krisbiantoro ${ }^{1}$, Sarmini ${ }^{2}$ \\ Program Studi Sistem Informasi, Fakultas Ilmu Komputer Universitas Amikom, Purwokerto ${ }^{1,2}$ \\ e-mail: dwikris@amikompurwokerto.ac.id ${ }^{1},{ }^{2}$ Sarmini@amikompurwokerto.ac.id ${ }^{2}$,
}

\begin{abstract}
Abstrak
Beberapa faktor yang mempengaruhi keberhasilan usaha rumah makan diantaranya adalah menu yang disajikan, kebersihan dan kenyamanan tempat serta pelayanan yang diberikan. Kecepatan dan kesesuaian pelayanan pada antrian menjadi salah satu hal yang perlu diperhatikan. Sebagian rumah makan di Purwokerto memang belum memiliki sistem antrian yang baik, sehingga beberapa masalah yang umum terjadi adalah antrian pada sebuah rumah makan pada saat pembayaran ataupun pada saat memesan dan hal ini berakibat pada ketidaksesuaian pelayanan, dan kekeliruan dalam melayani pelanggan. Tujuan penelitian ini adalah membuat sistem pembayaran dengan payment gateway sekaligus dapat memantau antrian di sebuah rumah makan berbasis android, sehingga pengguna aplikasi dapat dengan mudah memilih tempat rumah makan dan menu yang dipesan tanpa harus antri, selain itu dalam aplikasi ini memuat informasi antrian pemesanan pada suatu rumah makan, sehingga pengguna dapat memantau antrian yang banyak atau antrian yang sedikit. Pengembangan sistem pada penelitian yang dilakukan menggunakan model RUP (Rational Unified Process) yang didalamnya meliputi tahapan inception, elaboration, construction, transition. Hasil dari penelitian ini adalah berupa aplikasi payment gateway dan memantau antrian di sebuah rumah makan, hasil uji yang dilakukan terhadap aplikasi menggunakan black box testing dengan hasil aplikasi dapat berjalan sesuai dengan fungsinya.
\end{abstract}

Kata kunci : Android; Payment Gateway; RUP

\begin{abstract}
Some of the factors that influence the success of a restaurant business are the menus served, the cleanliness and comfort of the place and the services provided. In any business, service is one of the most important things and is able to influence the customer's assessment of a line of business, including restaurant businesses. The speed and suitability of services in the queue is one thing that needs attention. Some restaurants in Purwokerto do not yet have a good queue system, so some common problems that occur are queues at a restaurant at the time of payment or when ordering and this results in service mismatches, and errors in serving customers. The purpose of this study is to create a payment system with a payment gateway while simultaneously being able to monitor queues at an android-based restaurant. so application users can easily choose where restaurants and menus are ordered without having to queue, other than that in this application contains information queue reservations at a restaurant, so users can monitor a lot of queues or queues are few. System development in research conducted using the RUP (Rational Unified Process) model which includes the stages of inception, elaboration, construction, transition. The results of this study are in the form of a payment gateway application and monitor queues at a restaurant, the results of tests conducted on applications using black box testing with the results of the application can run according to function.
\end{abstract}

Keywords: Android; Payment Gateway; RUP 


\section{PENDAHULUAN}

Saat ini bisnis restoran dan rumah makan semakin banyak, tidak terkecuali untuk kota kecil seperti Purwokerto. Purwokerto merupakan salah satu kota dengan banyak bidang usaha didalamnya, salah satunya adalah rumah makan. Berdasarkan data yang diperoleh dari Dinas koperasi dan Industri kecil Jumlah Unit Usaha Aneka Makanan di Kabupaten Banyumas mencapai 7.156 unit usaha.

Faktor keberhasilan pada bisnis rumah makan bisa dilihat dari beberapa aspek diantaranya, menu yang disajikan, kebersihan dan kenyamanan tempat makan serta pelayanan yang diberikan. Tidak dipungkiri bahwa pelayanan pada setiap bisnis sangat mempengaruhi penilaian pelanggan terhadap unit bisnis tersebut, salah satunya adalah kecepatan dan kesesuaian pelayanan terhadap antrian pelanggan. Sebagian rumah makan di Purwokerto belum memiliki sistem antrian yang bisa dengan mudah diakses oleh pelanggan, pada umumnya pelayan sebuah rumah makan akan menyajikan pesanan berdasarkan kemudahan dalam mengolah makanan yang dipesan bukan sesuai antrian. Hal ini mengakibatkan terjadinya penurunan penilaian terhadap pelayanan setiap rumah makan. Belum lagi apabila sebelum datang ke lokasi, pelanggan tidak dapat mengetahui apakah rumah makan yang mereka tuju penuh, atau bahkan antrian pada rumah makan itu terlalu banyak. Pelanggan terpaksa berpindah tempat apabila setelah sampai ke rumah makan yang dituju ternyata tidak tersedia meja kosong dan antrian yang ada terlalu panjang.

Untuk pelanggan dengan status pegawai sebuah institusi yang memiliki keterbatasan jam istirahat hal ini tentu menjadi permasalahan, terlebih pada jam makan siang umumnya sebuah rumah makan akan sangat ramai. Beberapa solusi saat ini bermunculan seperti jasa delivery order yang disediakan oleh rumah makan, dan jasa pesan antar melalui aplikasi GoFood. Namun, kedua solusi itu juga memunculkan masalah baru karena tidak semua rumah makan menyediakan jasa delivery order. Selain itu jasa delivery order juga terpengaruh oleh harga minimal pemesanan dan banyaknya jumlah antrian yang ada. Sedangkan untuk jasa GoFood hanya menyediakan pilihan rumah makan yang menjadi partner GoJek, selain itu dengan menggunakan jasa GoFood harga makanan yang ada sudah mengalami kenaikan harga sehingga makanan yang ada menjadi lebih mahal dari yang sebenarnya. Berdasarkan data yang diperoleh dari Dinas Koperasi dan Industri kecil kab.banyumas perusahaan Dagang di Kabupaten Banyumas pada tahun 2017 terdiri dari 4 Perusahaan Dagang Besar, 106 Perusahaan Dagang Menengah dan 513 Perusahaan Dagang Kecil. Berdasarkan data tersebut dapat disimpulkan bahwa sebagian besar usaha di Kabupaten Banyumas merupakan Perusahaan Dagang Kecil dan tidak menyediakan jasa delivery order.

Penelitian sebelumnya telah banyak dikembangkan sistem informasi pemesanan makanan dan minuman baik yang berbasis website maupun berbasis android. Seperti halnya penelitian yang dilakukan [1], pada penelitian yang dilakukan bertujuan untuk membantu pengunjung rumah makan dalam melakukan pemesanan meja dan makanan secara online berbasis website. Penelitian yang serupa juga dilakukan [2] yang melakukan perancangan sistem informasi pemesanan makanan dan minuman pada restoran berbasis web dengan tujuan agar pelanggan tidak menunggu terlalu lama pesanannya sehingga operasional restoran dapat berjalan lebih efektif, aman, cepat dan akurat. Penelitian selanjutnya dilakukan [3], pada penelitian ini dilakukan perancangan dan implementasi kantin online berbasis android yang menyediakan layanan pemesanan dan pengiriman makanan ke tempat pemesan dengan menggunakan mobile apps. Penelitian lain dilakukan [4] yang merancang aplikasi sistem manajemen pemesanan menu restoran berbasis android untuk mempermudah proses pemesanan menu makanan dan minuman. Kemudian 
penelitian [5] yaitu membuat aplikasi pemesanan makanan dan minuman berbasis client server untuk mempermudah proses pemesanan yang dilakukan oleh pelanggan.

Pada penelitian yang dilakukan membahas tentang model antiran dan model pembayaran yang dilakukan menggunakan payment gateway dalam pemesanan makanan dan minuman. Adapun konsep aplikasi yang dikembangkan adalah calon pelanggan dapat menentukan pilihan rumah makan mulai dari kelas kecil, menengah hingga besar yang ada di Purwokerto. Pelanggan perlu mengetahui terlebih dahulu jumlah antrian dan ketersediaan meja kosong pada rumah makan, selain itu pelanggan juga dapat melihat jumlah antrian, ketersediaan meja kosong, memilih atau memesan meja kosong yang ada pada sebuah rumah makan secara online, mendapatkan notifikasi terkait pesanan mereka, dan mengetahui hasil review maupun rekomendasi terhadap sebuah rumah makan. Dan pada pengembangan aplikasi yang menjadi perbedaan dengan penelitian sebelumnya telah dilakukan adalah sistem pembayaran menggunakan payment gateway sehingga untuk rumah makan terkait tidak perlu khawatir adanya penipuan yang dilakukan pelanggan karena payment gateway menjamin keamanan pembayaran [6].

\section{TINJAUAN PUSTAKA}

Penelitian yang dilakukan oleh [7] dalam penelitiannya mengenai sistem pembayaran secara digital menggunakan payment gateway pada pemesanan paket wisata. Pada penelitian ini hanya menekankan pada proses pembayaran digital saja belum sampai ke tahap model antrian dalam pemesanan paket yang ditawarkan. Selanjutnya beberapa penelitian terkait pemesanan makanan telah dilakukan diantaranya adalah penelitian yang dilakukan oleh [8] dengan membangun sebuah software pemesanan makanan, penelitian ini menggunakan metode prototype yang dimulai dengan melakukan survey kebutuhan user terhadap software yang dirancang. Hasil akhir dari penelitian tersebut berupa aplikasi pemesanan makanan berbasis Android yang digunakan untuk memesan makanan dengan fitur in-app chat, status order dan fitur top up untuk mempermudah pengguna dan penjual saat melakukan transaksi pemesanan makanan. Namun, pada penelitiannya pelanggan tidak dapat melihat status antrian yang ada pada rumah makan dan hanya dapat digunakan untuk rumah makan yang sudah bekerja sama sebelumnya (partner).

Selanjutnya adalah penelitian yang dilakukan oleh [9] dengan membangun aplikasi hybrid jual beli kuliner untuk membantu proses transaksi jual beli antara penjual dan konsumen. Metode yang digunakan adalah Software Development Life Cycle (SDLC) dengan model prototype. Aplikasi hybrid jual beli kuliner dibangun menggunakan framework codeigniter dan phonegap dengan model pengembangan prototype yang terdiri dari tahap analisis kebutuhan, tahap desain, tahap implementasi dan tahap pengujian. Hasil yang diperoleh pada penelitian tersebut adalah $90 \%$ (baik) pada aspek tampilan, $90 \%$ (baik) pada struktur perangkat lunak, $95 \%$ (baik) pada fungsi penggunaan dan $65 \%$ (cukup baik) untuk penyediaan informasi. Pada penelitian tersebut pengguna dapat melakukan pencarian informasi mengenai produk kuliner, melakukan pembuatan akun sebagai member aplikasi, melakukan pemesanan, melihat informasi status pemesanan, dan konfirmasi pemesanan. Namun, untuk ketersediaan meja kosong dan jumlah antrian pada rumah makan belum tersedia. Selain itu, aplikasi yang dibuat hanya sebagai aplikasi pemesanan, tidak ada proses transaksi pembayaran didalamnya. 
Berdasarkan dari penelitian sebelumnya peneliti menawarkan sebuah konsep payment gateway dengan sistem antrian dirumah makan sehingga para pembeli dapat memperkirakan waktunya apakah akan memesan dirumah makan yang dituju atau pindah dengan melihat antrian yang ada pada sistem nantinya.

\subsection{Payment Gateway}

Payment Gateway Service adalah layanan $3 r d$ party service yang menghubungkan antara merchant dengan bank. Dengan tersedianya layanan tersebut maka merchant dapat menyediakan layanan online payment pada website online shopping-nya dengan cara menghubungkan website mereka pada payment gateway service menggunakan service dari Application Program Interface (API). Payment gateway service sangat dibutuhkan karena tingginya initial cost dan maintenance cost untuk melakukan koneksi dengan bank, selain dari pada itu dibutuhkan juga sebuah sistem yang dapat menghubungkan account bank dari customer dan merchant [10].

\subsection{Andorid}

Android adalah sebuah sistem operasi telepon seluler dan komputer tablet layar sentuh (touchscreen) yang berbasis linux [11]

Namun seiring perkembangannya, android berubah menjadi platform yang begitu cepat dalam malakukan inovasi. Hal ini tidak lepas dari pengembang utama dibelakangnya yaitu Google. Googleyang mengakusisi android, kemudian membuatkan sebuah platform.

Platform android terdiri dari sistem operasi berbasis linux, sebuah GUI (Graphic User Interface), sebuah web browser dan aplikasi end-user yang dapat di download dan juga para pengembang dapat dengan leluasa berkarya serta menciptakan aplikasi yang terbaik dan terbuka untuk digunakan oleh berbagai macam perangkat.

Android adalah sebuah sistem operasi untuk perangkat mobile berbasis linux yang mencakup sistem operasi, middleware dan aplikasi [12].

\section{METODOLOGI PENELITIAN}

Pada penelitian ini akan digunakan metode Rational Unified Process (RUP) yang merupakan sebuah metode untuk pembangunan sistem meliputi seluruh lifecycle pembangunan perangkat lunak. RUP menyediakan pendekatan untuk membantu tugas dan tanggung jawab suatu pembangunan organisasi dengan tujuan menghasilkan perangkat lunak yang berkualitas tinggi dan memenuhi kebutuhan pengguna. RUP merupakan metode yang dapat diprediksi jadwal dan biaya pengembangannya [13]

Langkah-langkah pada penelitian ini terdiri dari beberapa tahapan yaitu identifikasi masalah, pengumpulan data, dan pengembangan perangkat lunak dengan menggunakan metode RUP dapat dilihat pada gambar 1.

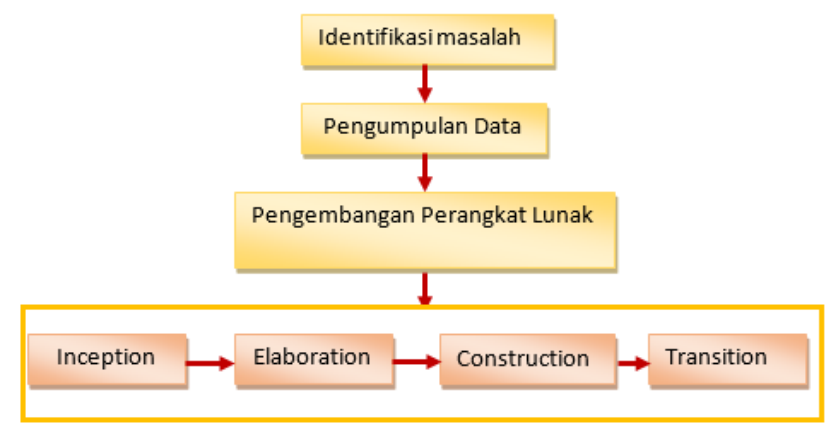

Gambar 1. Tahapan Penelitian

Sumber : Model Pengembangan RUP

Pada tahap identifikasi masalah dilakukan dengan melakukan pengamatan terhadap proses jual beli baik secara offline maupun online. Mulai dari proses pemesanan, pembayaran sampai proses antar pesanan. Selain itu dilakukan pengamatan terhadap pelayanan yang dilakukan sebuah 
rumah makan terhadap antrian pelanggan.

Serta dilakukan pengamatan terhadap syarat dan perubahan harga dalam pelayanan pesan antar disebuah rumah makan baik dengan menggunakan jasa delivery order maupun jasa GoFood. Pengamatan terhadap media pemesanan juga dilakukan untuk menganalisa kebutuhan sistem dan pengguna. Untuk tahapan yang kedua yaitu pengumpulan data yang dilakukan dengan mengumpulkan beberapa sampel rumah makan di Purwokerto beserta menu yang dijual. Untuk sampel rumah makan diambil dari beberapa kelas usaha yaitu mulai dari pedagang kaki lima, rumah makan tingkat menengah hingga restoran. Hal tersebut bertujuan untuk menganalisa tingkat kesiapan sistem yang akan dibuat sehingga bisa digunakan oleh berbagai kalangan. Pengumpulan data juga dilakukan dengan menggunakan berbagai literatur sebagai referensi dalam pengembangan sistem, selain itu juga dilakukan pengambilan data secara online dari media website bagi rumah makan yang memiliki website. Hal tersebut dilakukan untuk menganalisa keefektifan penjualan dengan menggunakan media online.

Untuk tahapan metode RUP terdiri dari beberapa tahapan yaitu inception pada fase ini yaitu dilakukan pemodelan terhadap proses bisnis dan dilakukan identifikasi kebutuhan dari sistem yang akan dibuat dengan menggunakan use case diagram dan activity diagram. Selanjutnya tahap elaboration, pada tahap ini fokus yang dilakukan adalah melakukan perencanaan arsitektur sistem yang akan dibangun. Tahap selanjutnya adalah construction pada tahapan ini dilakukan pengembangan komponen dan fitur sistem dimana tiap-tiap fitur yang ada memiliki berbeda fungsinya, hasil pengembangan komponen dan fitur sistem kemudian diimplementasikan dan selanjutnya dilakukan pengujian dari aplikasi dengan metode black box [14] pada tiap-tiap fitur yang ada dengan menguji tiap fitur apakah sudah berjalan sesuai dengan fungsinya atau belum. Tahapan yang terakhir adalah transition, dimana pada tahapan ini merupakan tahap instalasi sistem agar dapat dimengerti dan dipahami oleh pengguna (user). Pada tahap ini dilakukan pelatihan user, pemeliharan dan pengujian sistem apakah sudah sesuai dengan kebutuhan dan keinginan user.

\section{HASIL DAN PEMBAHASAN}

\subsection{Fase Inception}

Adapun model kebutuhan dalam aplikasi payment gateway ini dirancang dalam use case diagram Pada bagian ini akan dijabarkan hasil perancangan dari sistem yang dibuat yang digambarkan ke dalam use case dan diagram

aktivitas. Untuk use case dari penelitian ini ditunjukkan pada gambar 2 dibawah ini:

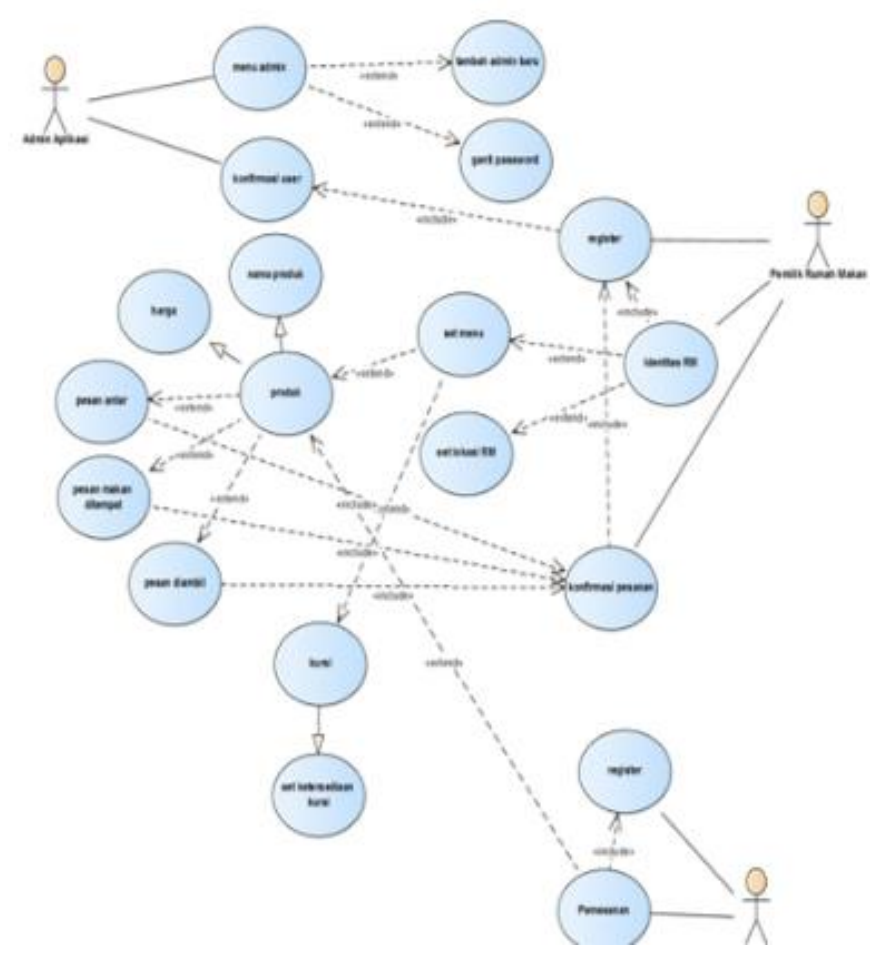

Gambar 2. Use Case Perancangan Aplikasi

Berdasarkan gambar 2 dapat dilihat bahwa pada penelitian ini terdapat tiga aktor yang berperan sebagai pengguna aplikasi. Ketiga aktor pengguna aplikasi tersebut yaitu admin aplikasi, pemilik rumah makan dan pelanggan. Masing-masing aktor memiliki hak aksesnya sendiri seperti yang telah 
digambarkan pada gambar 2. Admin aplikasi merupakan aktor yang berperan paling penting dalam berjalannya proses bisnis dengan memanfaatkan aplikasi ini. Admin aplikasi merupakan aktor yang memiliki hak untuk memberikan izin terhadap pemilik rumah makan yang mendaftar dalam penggunaan aplikasi ini. Admin aplikasi nantinya bisa menambahkan admin baru dan memberi izin bagi pemilik rumah makan yang mendaftar. Setelah admin memiliki akun masing-masing, admin mampu mengubah password mereka.

Aktor yang berikutnya yaitu pemilik rumah makan yang merupakan aktor utama pada aplikasi ini. Pemilik rumah makan memiliki paling banyak fitur yang bisa diakses dalam penggunaan aplikasi ini. Beberapa fitur yang bisa diakses oleh pemilik rumah makan adalah menu register, identitas rumah makan dan konfirmasi pesanan. Sebelum masuk ke menu identitas rumah makan dan konfirmasi pesanan, setiap pemilik rumah makan harus melakukan registrasi terlebih dahulu. Apabila pemilik rumah makan sudah melakukan registrasi harus menunggu konfirmasi dari admin aplikasi terlebih dahulu. Apabila data registrasi sudah dikonfirmasi, pemilik rumah makan melakukan pengisian identitas rumah makan. Pada pengisian identitas rumah makan, pemilik rumah makan bisa menginputkan produk-produk yang dijual dan juga melakukan pengesetan lokasi rumah makan, beserta jumlah kursi yang tersedia pada rumah makan tersebut. Selanjutnya, pada menu konfirmasi pesanan pemilik rumah makan bisa melakukan konfirmasi apabila produk (makanan) yang dipesan tidak tersedia atau habis, begitu pula untuk ketersediaan kursi dan kesediaan pesan antar.

Aktor yang terakhir yaitu pelanggan dengan dua fitur atau menu diantaranya adalah menu registrasi dan pemesanan. Sebelum melakukan pemesanan, pelanggan harus melakukan resitrasi terlebih dahulu kemudian setelah itu pelanggan baru bisa melakukan pemesanan. Pada menu pemesanan, pelanggan melakukan pemilihan produk terlebih dahulu kemudian akan ada pilihan opsi setelah melakukan pemesanan yaitu pesan antar, pesan diambil atau pesan tempat.

\subsection{Fase Elaboration}

Pada fase ini dilakukan perancangan logika prosedural pada sistem yang akan dibangun menggunakan activity diagram dan rancangan dari arsitektur sitem yang dibuat. Berdasarkan gambar 2 dapat dilihat bahwa proses pemesanan melibatkan dua aktor yaitu pelanggan dan pemilik rumah makan. Adapun alur dari pemesanan dimulai dari pelanggan yang melakukan pemesanan produk sesuai apa yang mereka pilih dari berbagai rumah makan yang telah terdaftar diaplikasi tersebut. Apabila pelanggan telah melakukan pemesanan selanjutnya pelanggan harus menunggu konfirmasi dari rumah makan yang dipilih terlebih dahulu, apabila pesanan tidak tersedia maka sistem akan memberikan notifikasi bahwa pesanan telah habis atau tidak tersedia. Sedangkan apabila pesanan masih tersedia maka pemilik rumah makan akan menekan tombol konfirmasi yang menyatakan pesanan diterima. 


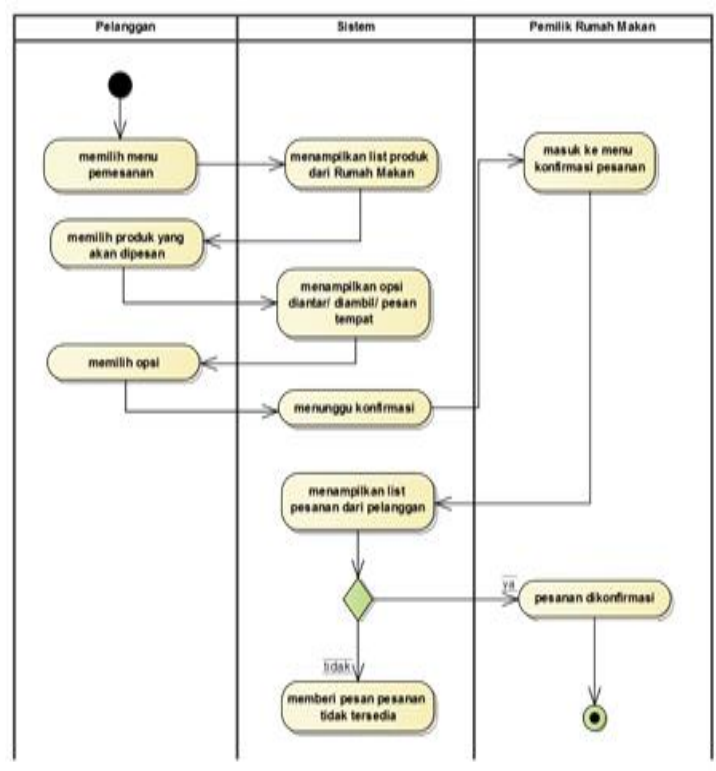

Gambar 3. Diagaram Aktivitas Pemesanan

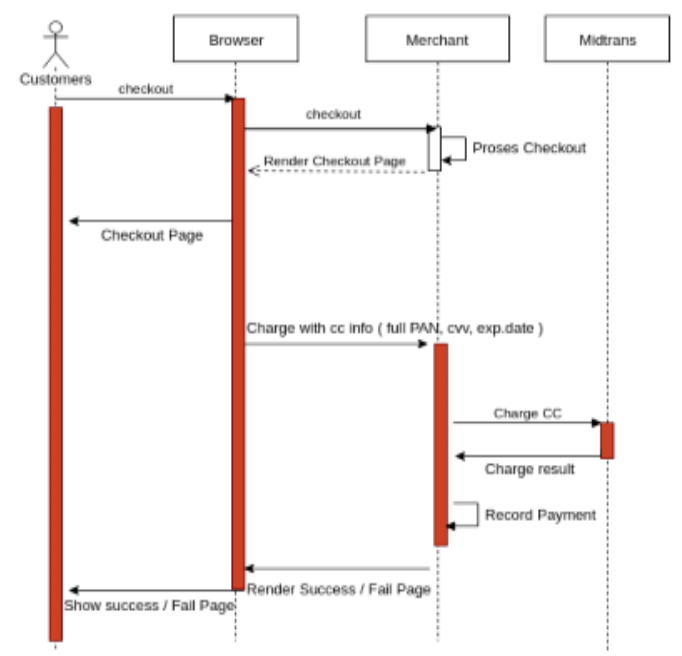

Gambar 4. Sequence Diagaram Pembayaran

Adapun rancangan dari arsitektur dari payment gateway yang dirancang adalah sebagai berikut dapat dilihat pada gambar 5 .

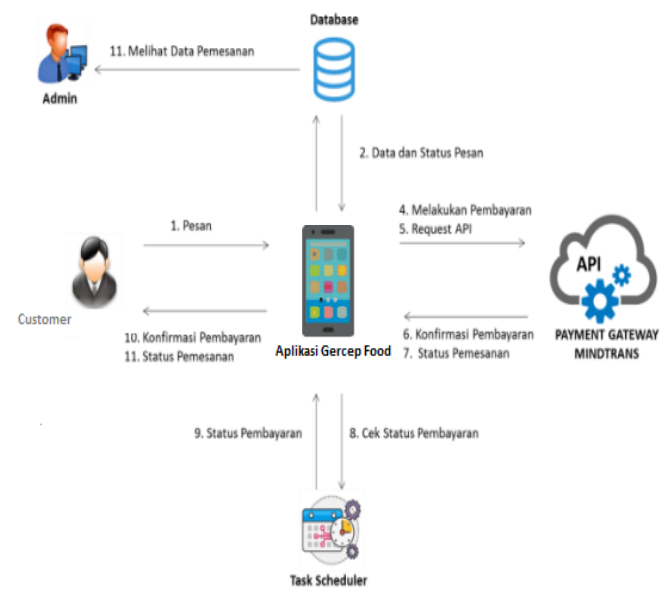

Gambar 5. Arsitektur Sistem

Dapat dijelaskan dari gambar 5 arsitekur yang akan dikembangkan adalah pelanggan melakukan pemesanan makanan dari rumah makan yang sudah melakukan registrasi ke sistem gercep food,kemudian pesanan akan diterima oleh admin rumah makan dan tersimpan pada database lalu customer akan melakukan pembayaran dengan melakukan request pada API midtrans, selanjutnya customer menerima konfirmasi dan status pembayaran dari API midtrans untuk melakukan pembayaran langsung atau menunda pembayaran. Pembayaran dengan memanfaatkan layanan API sandbox dari midtrans dibangun menggunakan konsep SOA.Ketika customer melakukan pembayaran pada midtrans maka, aplikasi Gercep Food akan melakukan pengecekan status pembayaran menggunakan task scheduler setiap 1 menit sekali. Setelah dilakukan pengecekan status pembayaran maka data pemesan pada database terkait status pembayaran akan mengalami pembaruan secara otomatis. Jika status pembayaran sukses maka aplikasi gercep food akan memberikan notifikasi pada customer. Kemudian data pemesanan dapat dilihat oleh admin pada database. 


\subsection{Fase Construction}

1. Tahap Implementasi

Hasil dari penelitian yang telah dilakukan diterapkan pada rumah makan di purwokerto dengan bahasa pemrograman android studio dan database SQL Lite.

2. Tampilan Menu

a. Halaman splash screen merupakan halaman saat aplikasi dijalankan. Adapun untuk user interface dari halaman splash screen ditunjukkan pada gambar 6.

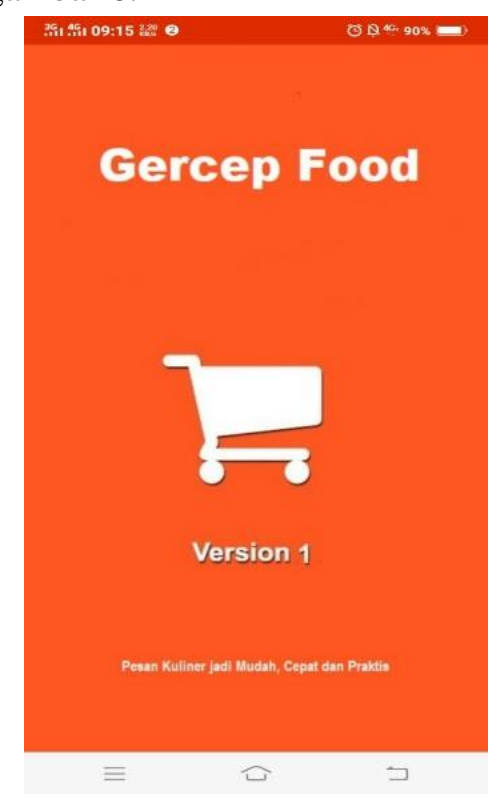

Gambar 6. Tampilan Splash Screen

b. Halaman Utama, Pada halaman ini ditampilkan dilihat beberapa fitur yang tersedia pada menu utama dari aplikasi Gercep Food diantaranya menu cari kuliner, menu cart, menu checkout, menu informasi, menu profile dan menu about aplikasi.

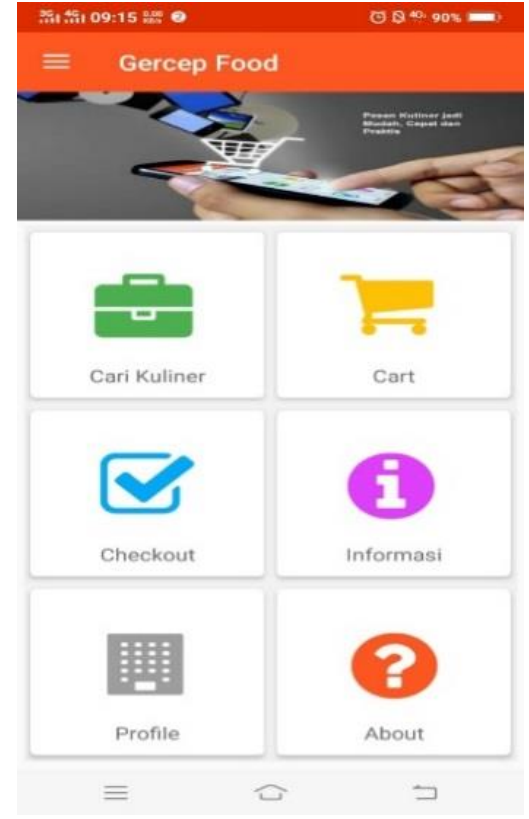

Gambar 7. Tampilan Utama Aplikasi Gercep Food

c. Halaman Utama Pembeli menu ini digunakan untuk pemilik rumah makan dan admin yang sudah registrasi. Apabila pengguna aplikasi belum melakukan registrasi maka beberapa fitur yang bisa digunakan hanya fiturfitur untuk pelanggan/pembeli.

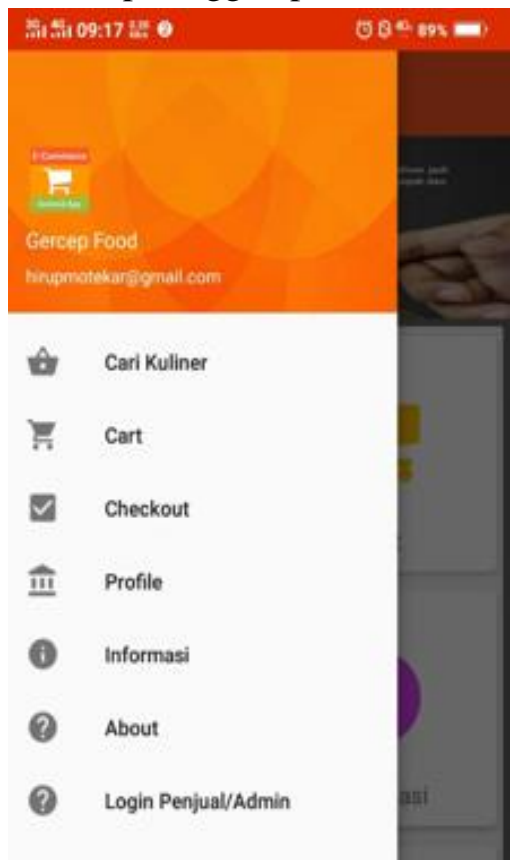

Gambar 8. Tampilan Halaman Utama Pembeli 
d. Halaman Penjual, Halaman ini berisi tentang pengelolaan rumah makan oleh penjual diantaranya kelola menu, meja yang nantinnya dari perubahan yang dilakukan penjual dapat terlihat di menu pembeli.
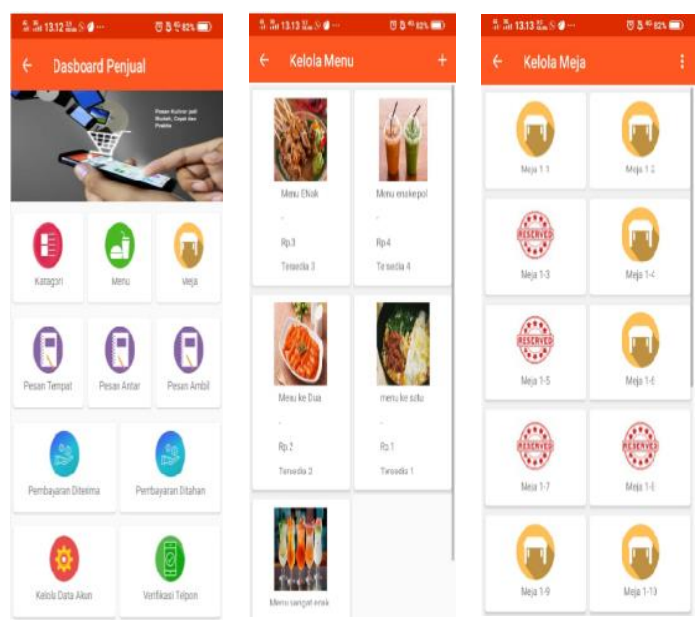

Gambar 9. Tampilan Halaman Penjual

e. Halaman implementasi payment Gateway

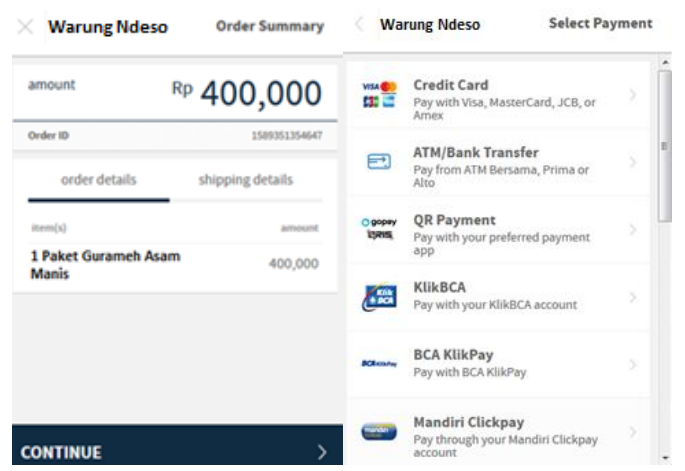

Gambar 10. Tampilan Halaman Payment Gateway

\subsection{Fase Transition}

Fase dimana dilakukan tahap pengujian dan instalasi sebelum diterapkan atau dijalanakan pada rumah makan yang ada di purwokerto. Dalam fase ini dilakukan pengujian terhadap fungsionalitas pada aplikasi yang telah dibuat dengan metode Black Box Testing. Pada pengujian blackbox testing dilakukan agar pengembang mengetahui apakah aplikasi sudah berjalan sesuai dengan yang diinginkan. Berikut ini adalah hal yang di ujikan pada pengujian Blackbox testing terhadap antarmuka dari pihak Pelanggan

Tabel 1 Pengujian Black Box Testing Antarmuka Pelanggan Rumah Makan

\begin{tabular}{|c|c|c|c|c|}
\hline $\mathrm{N}$ & Deskripsi & $\begin{array}{l}\text { Hasil yang } \\
\text { diharapkan }\end{array}$ & $\begin{array}{l}\text { Hasil } \\
\text { Uji }\end{array}$ & $\begin{array}{l}\text { Kesimpula } \\
\text { n }\end{array}$ \\
\hline 1 & $\begin{array}{l}\text { Otentikas } \\
\mathrm{i} \text { dan } \\
\text { verifikasi } \\
\text { halaman } \\
\text { login }\end{array}$ & $\begin{array}{l}\text { Jika } \\
\text { username } \\
\text { dan password } \\
\text { yang } \\
\text { dimasukkan } \\
\text { benar masuk } \\
\text { ke sistem, } \\
\text { jika tidak } \\
\text { ditolak }\end{array}$ & $\begin{array}{l}\text { Sesua } \\
\mathrm{i}\end{array}$ & $\begin{array}{l}\text { Berjalan } \\
\text { baik }\end{array}$ \\
\hline 2 & $\begin{array}{l}\text { Menu cari } \\
\text { kuliner }\end{array}$ & $\begin{array}{l}\text { Muncul list } \\
\text { rumah makan } \\
\text { yang sudah } \\
\text { dipesan }\end{array}$ & $\begin{array}{l}\text { Sesua } \\
\mathrm{i}\end{array}$ & $\begin{array}{l}\text { Berjalan } \\
\text { baik }\end{array}$ \\
\hline 3 & Menu cart & $\begin{array}{l}\text { Menampilka } \\
\mathrm{n} \quad \text { daftar } \\
\text { pesanan yang } \\
\text { sudah } \\
\text { dipesan }\end{array}$ & $\begin{array}{l}\text { Sesua } \\
\text { i }\end{array}$ & $\begin{array}{l}\text { Berjalan } \\
\text { baik }\end{array}$ \\
\hline 4 & $\begin{array}{l}\text { Menu } \\
\text { checkout }\end{array}$ & $\begin{array}{l}\text { Menampilka } \\
\mathrm{n} \text { form } \\
\text { pembayaran } \\
\text { dan jenis } \\
\text { layanan yang } \\
\text { harus dipilih }\end{array}$ & $\begin{array}{l}\text { Sesua } \\
\mathrm{i}\end{array}$ & $\begin{array}{l}\text { Berjalan } \\
\text { baik }\end{array}$ \\
\hline 5 & $\begin{array}{l}\text { Menu } \\
\text { informasi }\end{array}$ & $\begin{array}{l}\text { Menampilka } \\
\mathrm{n} \text { informasi } \\
\text { cara belanja, } \\
\text { pembayaran } \\
\text { dan kontak } \\
\text { yang dapat } \\
\text { dihubungi }\end{array}$ & $\begin{array}{l}\text { Sesua } \\
\mathrm{i}\end{array}$ & $\begin{array}{l}\text { Berjalan } \\
\text { baik }\end{array}$ \\
\hline 6 & $\begin{array}{l}\text { Menu } \\
\text { profile }\end{array}$ & $\begin{array}{l}\text { Menampilka } \\
\mathrm{n} \text { deskripsi } \\
\text { pelanggan }\end{array}$ & $\begin{array}{l}\text { Sesua } \\
\mathrm{i}\end{array}$ & $\begin{array}{l}\text { Berjalan } \\
\text { baik }\end{array}$ \\
\hline 7 & $\begin{array}{l}\text { Menu } \\
\text { about }\end{array}$ & $\begin{array}{l}\text { Menampilka } \\
\text { n deskripsi } \\
\text { aplikasi }\end{array}$ & $\begin{array}{l}\text { Sesua } \\
\mathrm{i}\end{array}$ & $\begin{array}{l}\text { Berjalan } \\
\text { baik }\end{array}$ \\
\hline
\end{tabular}

\section{KESIMPULAN}

Berdasarkan hasil yang diperoleh pada penelitian ini, aplikasi yang dibuat mampu digunakan sebagai salah satu alternatif dalam mengatasi permasalahan yang telah dirumuskan sebelumnya. Penelitian ini memberikan solusi untuk para pelanggan yang menghindari 
panjangnya antrian pada sebuah rumah makan, karena pelanggan mampu melihat ketersediaan kursi terlebih dahulu sebelum datang ke rumah makan tersebut.

\section{SARAN}

Untuk penelitian selanjutnya diharapkan dapat mengembangkan aplikasi ini dengan fitur yang lebih lengkap dan memungkinkan untuk terintregrasi dengan sistem yang ada di tiap rumah makan. Sehingga, pemilik rumah makan tidak perlu melakukan pemeriksaan satu persatu dari ketersediaan kursi kosong yang ada di rumah makan, tapi apabila pelanggan yang duduk pada nomor meja tertentu telah melakukan pembayaran pada kasir untuk ketersediaan kursi bisa terupdate secara otomatis.

\section{DAFTAR PUSTAKA}

[1] D. Miyadi and Sukatmi, "Membangun Sistem Informasi Pemesanan Meja Dan Makanan Berbasis Web (Studi Kasus: Rumah Makan Mbak Tuti)," J. ONESISMIK, vol. 3, no. 3, pp. 218-226, 2019, [Online]. Available: https://jurnal.dcc.ac.id/index.php/one sismik/article/view/306.

[2] D. Ong, "Analisa Dan Perancangan Sistem Informasi Pemesanan Menu Makanan Dan Minuman Pada Restoran Menggunakan Codeigniter," J. Teknol. Inf., vol. XV, no. 3, pp. $1-$ 11, 2020.

[3] A. Nalariza and T. Sugiarso, "Perancangan dan Implementasi 'Kantin Online' Berbasis Android," Teknol. Inf., vol. 2, no. 3, pp. 124 130, 2016.

[4] L. F. Israwan, H. Hamsinar, and N. Anggriani, "Manajemen Pemesanan Menu Restoran Berbasis Android Application Design of Android-Based Restaurant Menu Booking Systems," Informatika, vol. 5, no. 2, 2016.

[5] D. Utama, A. Johar, and F. F.
Coastera, "Minuman Restaurant Berbasis Client Server Dengan P Latform Android," Rekursif, vol. 4, no. 3, pp. 288-300, 2016.

[6] N. Farkhatin, "Perancangan Sistem Informasi Pembayaran," JSM STMIK Mikroskil, vol. 13, no. 1, pp. 63-71, 2012.

[7] T. M. M. Puspasari and D. Maulina, "Digitalisasi Pembayaran Marketplace Menggunakan Midtrans Payment Gateway," vol. 1, no. 1, pp. 22-28, 2019.

[8] I. Darmawan, F. M. Al-anshary, and A. Salma, "Perancangan Aplikasi Callme Berbasis Android Menggunakan Metode Prototyping (Modul Administrasi Customer Dan Admin) Design," e-Proceeding Eng., vol. 4, no. 2, pp. 3057-3064, 2017.

[9] N. Yuliansyah, S. Khair, and Y. Mulyanto, "Membangun Aplikasi Hybrid Jual Beli Kuliner Di Kota Sumbawa Menggunakan Codeigniter Dan Phonegap," J. TAMBORA, vol. 2, no. 2, 2017, doi: 10.36761/jt.v2i2.160.

[10] H. Akbar, M. N. Hisyam, and M. B. Legowo, "Payment Gateway on E Canteen Website Application," no. 2016, pp. 108-112, 2019.

[11] Akhmad Dharma Kasman, Kolaborasi Dahsyat Android dengan PHP \& MYSQL, LokoMedia, Yogyakarta, no. 2013.

[12] S. Nazruddin, Pemrograman aplikasi mobile smartphone dan tablet PC berbasis Android, 1st ed. Bandung: Informatika, 2012.

[13] G. Booch, R. A. Maksimchuk, M. W. Engle, B. J. Young, J. Connallen, and K. A. Houston, "Object-oriented analysis and design with applications, third edition," ACM SIGSOFT Softw. Eng. Notes, 2008, doi: 10.1145/1402521.1413138. 
[14] A. . Rosa and S. M, "Rekayasa

Perangkat Lunak Terstruktur," in

Informatika, 2013. 